\title{
Effects of genetic and non genetic factors on production performance of primiparous Kankrej cattle
}

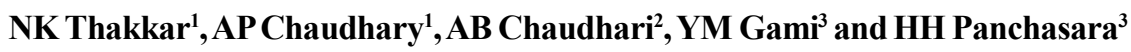

Received: 20 April 2021 / Accepted: 23 August 2021 / Published online: 31 October 2021

(C) Indian Dairy Association (India) 2021

\begin{abstract}
The present investigation included the records of 294 Kankrej cows, sired by 66 sires spread over a period of 20 years (1996 to 2015) maintained at Livestock Research Station, Sardarkrushinagar Dantiwada Agricultural University, Sardarkrushinagar, Gujarat. The effects of genetic and non genetic factors on performance traits (Daily Milk Yield, 305 Days Milk Yield, Total Milk Yield and Lactation Length) of primiparous Kankrej cows was studied. The least square means of daily milk yield, 305 days milk yield, total milk yield and lactation length were calculated and found $6.71 \pm 0.14,1893.42 \pm 60.00,1983.29 \pm 72.47$ $\mathrm{kg}$ and $290.78 \pm 7.33$ days, respectively. The season and period of calving did not affect these traits, while effects of sire was significant $(* \mathrm{P}<0.05)$ on $305 \mathrm{DMY}$, but it did not have any effect on the traits such as DMY, TMY and LL of primiparous Kankrej cow. On the basis of these observations, we can suggest that proper management practices as well as use of better sire will help to improve the production performance of the herd.
\end{abstract}

Keywords: Kankrej cow, Genetic factors, Performance traits

\footnotetext{
${ }^{1}$ Department of Livestock Production and Management, College of Veterinary Science and AH, Kamdhenu University, Sardarkrushinagar campus -385506

${ }^{2}$ Department of Animal Genetic and Breeding, College of Veterinary Science and AH, Kamdhenu University, Sardarkrushinagar campus - 385 506

3 Livestock Research Station, S D Agricultural University, Sardarkrushinagar-385 506

AP Chaudhary $(\square)$

Department of Livestock Production and Management, College of Veterinary Science and AH, Kamdhenu University, Sardarkrushinagar campus -385506, Dist- Banaskantha, State- Gujarat

Email: apc.lpm.sdau@gmail.com
}

\section{Introduction}

Livestock sector plays an important role in the livelihoods security of dairy farmers in the country. The rural economy mainly depends on agriculture and allied sector, where animal husbandry and dairy development plays an important role through supplementing the income of rural households, particularly, the landless, small and marginal farmers. Milk production is the enterprise in which the small scale farmers can easily engage themselves in order to improve their livelihood and regular income from selling of milk moves them from subsistence to a market based income. India continues to be the largest producer of milk in the world, since last decades, where government initiated several measures to increase the productivity of livestock, which has resulted in increasing the milk production significantly from the level of 17.0 million ton. in 1951 to 187.7 million ton during 2018-19 (Anonymous, 2019). At present availability of milk per head per day in the country is 394 grams (2018-19), which was only 132 grams in 1951.

The viability of a dairy farm is depends upon the performance of the animals reared for milk production, where daily milk yield records are important to know the milk ability of individual animals. It is also important that success of dairy enterprise is depends upon efficiency of production performance of the herd. There are several non genetic factors which influence the phenotypic value of economic traits, and the absence of accurate value of these traits make it difficult to estimate genetic parameters of the traits which determine optimum selection criterion for planned improvement of the animals (Dass and Sadana, 2000). Therefore, in present investigation was undertaken to study the effects of various genetic and non-genetic factors on (Daily Milk Yield, 305 Days Milk Yield, Total Milk Yield and Lactation Length) of primiparous Kankrej cow.

\section{Materials and Methods}

The present study was conducted to know the effects of genetic and non genetic factors on production performance traits of 294 Kankrej cattle maintained at Livestock Research Station, Sardarkrushinagar Dantiwada Agricultural University, Sardarkrushinagar, Gujarat. Geographically, Livestock Research 
Station, Sardarkrushinagar Dantiwada Agricultural University, Sardarkrushinagar is located in the north Gujarat. The climate of the farm is semi-arid in nature. Management practices followed on the farm were uniform for the herd. All animals were housed under loose housing system with adequate sheds for shelter against sun, rain and extreme winter. All animals at the farm were stall fed with dry roughages, green fodder and concentrate in proper proportion. The animals having lactation length less than 100 days, incomplete lactation due to sale or death during lactation, abortion and still birth etc. were considered as abnormal lactation and not included in the study. The data pertaining Kankrej cows was maintained over a period of 20 years from 1996 to 2015. The data was grouped into 4 periods with duration of 5 years viz. P1: 1995-2000, P2: 2001-2005, P3: 2006-2010 and P4: 2011-2015. Each year was delineated into 3 seasons each with duration of 4 months viz. S1: Nov.- Feb (winter)., S2: March- June (summer) and S3: July- Oct. (monsoon). The traits included in the study were Daily Milk Yield, 305 Days Milk Yield, Total Milk Yield and Lactation Length.

The period of calving and season of calving were considered as fixed effects and sire was considered as random effects for all traits. Single trait analyses was done by fitting a general linear model (GLM) to study the effect of various fixed effects on each production traits using SPSS v.20.0 software. To study the effects of genetic and non-genetic factors on DMY, 305 DMY, TMY and LL record of Kankrej cattle. The following model was used:

$$
\begin{aligned}
& \mathrm{Y}_{\mathrm{ijkl}}=\mu+\mathrm{A}_{\mathrm{i}}+\mathrm{B}_{\mathrm{j}}+\mathrm{C}_{\mathrm{k}}+\mathrm{e}_{\mathrm{ij} \mathrm{kl}} \\
& \mathrm{Y}_{\mathrm{i} \mathrm{j} \mathrm{kl}}=\text { Observation for the trait } \\
& \mu \quad=\quad \text { Overall mean } \\
& \mathrm{A}_{\mathrm{i}} \quad=\quad \text { fixed effect of } \mathrm{i}^{\text {th }} \text { period of calving } \\
& \mathrm{B}_{\mathrm{j}} \quad=\quad \text { fixed effect of } \mathrm{j}^{\text {th }} \text { season of calving } \\
& \mathrm{C}_{\mathrm{k}}=\text { Random effect of } \mathrm{k}^{\text {th }} \text { sire } \\
& \mathrm{e}_{\mathrm{ijkl}}=\quad \text { residual random error }(1), \operatorname{NID}\left(0, \sigma^{2}\right)
\end{aligned}
$$

The pair-wise comparison of subclass means within each fixed effect was done by Duncan's Multiple Range Test (DMRT).

\section{Results and Discussion}

The present investigation was conducted at Livestock Research Station, Sardarkrushinagar Dantiwada Agricultural University, Sardarkrushinagar, District-Banaskantha Gujarat to know the effects of genetic and non genetic factors evaluate the performance of Kankrej herd maintained from 1996-2015. The climatic conditions of the region is semi arid, where summer is dry and hot and temperature goes up to $40 \mathrm{U} C$, while winter is not stressful as average temperature remains from $10 \mathrm{U}$ C to $30 \mathrm{U}$ C with relative humidity $69 \%$ and $48 \%$ in morning and afternoon, respectively. The data pertaining to DMY, 305 DMY, TMY and LL was recorded from the records of the farm and analyzed the effects of non genetic factors like, season, period and genetic factors like sire was studied and result are mentioned in table: 1 .

\section{Daily Milk Yield (DMY)}

The average Daily Milk Yield (DMY) of primiparous Kankrej cow based on 291 number of observation was $6.71 \pm 0.14 \mathrm{~kg}$ (Table: 1). The values of DMY are in close agreement with Singh and Singh (2016) as $5.94 \pm 0.10 \mathrm{~kg}$ for Sahiwal cattle. The value was contrast with the findings of Ageeb and Hayes (2000) and Ayeneshet et al. (2018) for cattle.

The performance of Kankrej cow, calving during summer, monsoon and winter season was $6.80 \pm 0.18 \mathrm{~kg}, 6.65 \pm 0.22 \mathrm{~kg}$ and $6.66 \pm 0.18 \mathrm{~kg}$, respectively. It was highest during summer season $(6.80 \pm 0.18 \mathrm{~kg})$, and least during monsoon season $(6.65 \pm 0.22$ $\mathrm{kg}$ ). The DMY values were not significantly differ (Table: 1 ) for primiparous cow. The effect of season of calving was nonsignificant on DMY for primiparous Kankrej cattle and it is in close agreement with Singh and Singh (2016) and Vinoo et al. (2005) for Sahiwal cattle and Ongole cattle respectively, while the results are in contrast with findings of Ayeneshet et al. (2018). In, table 1. result reveled that DMY of primiparous Kankrej cattle for different seasons was not significantly differ from each other.

Similarly, DMY of the Kankrej cattle was $7.19 \pm 0.53 \mathrm{~kg}, 6.73 \pm$ $0.31 \mathrm{~kg}, 6.16 \pm 0.27 \mathrm{~kg}$ and $6.74 \pm 0.27 \mathrm{~kg}$ during different periods of calving viz; P1, P2, P3 and P4 respectively. The highest DMY was observed during $\mathrm{P} 1$ period $(7.19 \pm 0.53 \mathrm{~kg})$, whereas it was least during $\mathrm{P} 3$ period $(6.16 \pm 0.27 \mathrm{~kg})$ in primiparous cow. The period of calving have non-significant effect (Table 1) on DMY and it is in agreement with Bala et al. (2017) for White Fulani cow. These findings are contradictory with the findings of Singh and Singh (2016) for Sahiwal cattle. In, Table 1. result revealed that DMY of primiparous Kankrej cattle for different periods was not significantly differ from each other. Similarly, sire had nonsignificant effect on DMY for primiparous Kankrej cow (Table 1).

\section{Days Milk Yield (305 DMY)}

The least square means of 305 DMY of primiparous Kankrej cow based on 294 number of observation was $1893.42 \pm 60.00 \mathrm{~kg}$ (Table: 1). These values of 305 DMY are in agreement with Ekka (2014) as $1854.18 \pm 84.56 \mathrm{~kg}$ for Kankrej cattle. The finding value was contrast with the findings of Rehman et al. (2008), Singh et al. (2018) and Rathod et al. (2020) for Indigenous cattle.

The performance of primiparous Kankrej cow, during summer, monsoon and winter season was $1910.98 \pm 74.27 \mathrm{~kg}, 1899.78 \pm$ $90.74 \mathrm{~kg}$ and $1870.41 \pm 71.28 \mathrm{~kg}$, respectively. It was highest during

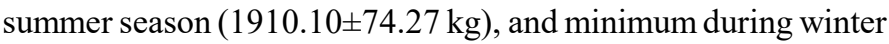
season $(1870.41 \pm 71.28 \mathrm{~kg})$. However, effect of season of calving 
Table: 1 Least Square Means of production traits of primiparous Kankrej Cows

\begin{tabular}{lllll}
\hline Factors & DMY $(\mathrm{Kg})$ & 305 DMY $(\mathrm{Kg})$ & TMY $(\mathrm{Kg})$ & LL $($ days $)$ \\
\hline Estimated Mean $(\mu \pm$ S.E. $)$ & $6.61 \pm 0.08(291)$ & $1902.97 \pm 31.42(294)$ & $1992.46 \pm 37.76(294)$ & $297.76 \pm 3.62(293)$ \\
Population Mean & $6.71 \pm 0.14(291)$ & $1893.42 \pm 60.00(294)$ & $1983.29 \pm 72.47(294)$ & $290.78 \pm 7.33(293)$ \\
Season of calving & $\mathrm{NS}$ & $\mathrm{NS}$ & $\mathrm{NS}$ & $\mathrm{NS}$ \\
Winter(S-1) & $6.66 \pm 0.18(116)$ & $1870.41 \pm 71.28(119)$ & $1954.02 \pm 86.07(119)$ & $288.14 \pm 8.70(118)$ \\
Summer(S-2) & $6.80 \pm 0.18(127)$ & $1910.10 \pm 74.27(127)$ & $2001.68 \pm 89.69(127)$ & $291.63 \pm 9.09(127)$ \\
Monsoon(S-3) & $6.65 \pm 0.22(48)$ & $1899.78 \pm 90.74(48)$ & $1994.19 \pm 109.57(48)$ & $292.55 \pm 11.08(48)$ \\
Period & $\mathrm{NS}$ & $\mathrm{NS}$ & $\mathrm{NS}$ & $\mathrm{NS}$ \\
$1996-2000(\mathrm{P}-1)$ & $7.19 \pm 0.53(35)$ & $1975.23 \pm 220.54(37)$ & $2084.35 \pm 266.32(37)$ & $280.61 \pm 26.94(37)$ \\
$2001-2005(\mathrm{P}-2)$ & $6.73 \pm 0.31(72)$ & $2015.90 \pm 130.66(72)$ & $2139.34 \pm 157.79(72)$ & $313.55 \pm 15.99(72)$ \\
$2006-2010(\mathrm{P}-3)$ & $6.16 \pm 0.27(93)$ & $1705.76 \pm 114.74(94)$ & $1752.23 \pm 138.55(94)$ & $282.97 \pm 14.07(93)$ \\
$2011-2015(\mathrm{P}-4)$ & $6.74 \pm 0.27(91)$ & $1876.83 \pm 114.73(91)$ & $1956.77 \pm 138.55(91)$ & $285.97 \pm 14.01(91)$ \\
Sire & $\mathrm{NS}$ & $*$ & $\mathrm{NS}$ & $\mathrm{NS}$ \\
\hline
\end{tabular}

Figures in parenthesis indicates number of observation/records., $* * \mathrm{P}<0.01$ highly significant; $* \mathrm{P}<0.05$ significant; NS $=\mathrm{Non}$ significant; S.E.= Standard Error; N= Subclass means with different superscripts are significantly different from each other

on 305 DMY of primiparous cow was non significant (Table 1) and it is in close agreement with Ekka (2014); Shingare et al. (2015) and Gaikwad et al. (2018) for Kankrej cattle, Deoni cattle and Phule Triveni cattle, respectively. Whereas, it is in contrast with the findings of Kakati et al. (2017). In Table 1 result also revealed that $305 \mathrm{DMY}$ was not differed significantly with each other.

The average 305 DMY of the primiparous Kankrej cow during different periods of calving viz; P1, P2, P3 and P4 was 1975.23 \pm $220.54 \mathrm{~kg}, 2015.90 \pm 130.66 \mathrm{~kg}, 1705.76 \pm 114.74 \mathrm{~kg}$ and $1876.83 \pm$ $114.73 \mathrm{~kg}$, respectively. The highest $305 \mathrm{DMY}$ was observed in P2 period (2015.90 $\pm 130.66 \mathrm{~kg})$ and lowest during P3 period $(1705.76 \pm 114.74 \mathrm{~kg})$, but these 305 DMY values were nonsignificant effect (Table: 1). These findings are in close agreement with Singh et al. (2016) for Karan-Fries cattle. The present results are not match with the findings of Gaikwad et al. (2018). In table 1. result revealed that 305 DMY of primiparous Kankrej cattle for different periods was not significantly differing from each other.

The least square analysis has revealed sire have significant $(\mathrm{P}<0.05)$ effect on $305 \mathrm{DMY}$ of primiparous Kankrej herd and it is in close agreement with the findings of Singh et al. (2020) in HF cattle. These results are in contrast with the findings of Mandal and Sachdeva (2001) for crossbred cattle.

\section{Total Milk Yield (TMY)}

The average TMY of primiparous Kankrej cow based on 294 number of observation was $1983.29 \pm 72.47 \mathrm{~kg}$ (Table 1). These values are in accordance with the reports of Kishore et al. (2016) and Kumar et al. (2016a) as $2021.08 \pm 42.80 \mathrm{~kg}$, and $2177.61 \pm 62.06$ $\mathrm{kg}$ for Tharparkar cattle and Crossbred cows. The present findings are contradictory with the findings of Chaudhary (2016 lo-cit), Bhutkar et al. (2014) and Rathod et al. (2020) for indigenous cattle.
The performance of primiparous Kankrej cow, during summer, monsoon and winter season was $2001.68 \pm 89.69 \mathrm{~kg}, 1994.19 \pm$ $109.57 \mathrm{~kg}$ and $1954.02 \pm 86.07 \mathrm{~kg}$, respectively. It was highest during summer season $(2001.68 \pm 89.69 \mathrm{~kg})$ and lowest during winter season $(1954.02 \pm 86.07 \mathrm{~kg})$. The value of TMY was not significant (Table 1) among primiparous cow. These findings are in close agreement with Ekka (2014) for Kankrej cattle and Singh and Singh (2016) and Narwaria et al. (2017) for Sahiwal cattle. In contrast to present results the findings of Singh et al. (2017) found that season of calving have significant effect on TMY. In Table 1 result revealed that TMY of Kankrej cows was not differ significantly with each other.

The average TMY of the primiparous Kankrej cow during different periods of calving viz; P1, P2, P3 and P4 was $2084.35 \pm 266.32 \mathrm{~kg}$, $2139.34 \pm 157.79 \mathrm{~kg}, 1752.23 \pm 138.55 \mathrm{~kg}$ and $1956.77 \pm 138.55 \mathrm{~kg}$ respectively. The highest TMY was observed during P2 period $(2139.34 \pm 157.79 \mathrm{~kg})$ and lowest during P3 period (1752.23 \pm $138.55 \mathrm{~kg}$ ). The period of calving have non-significant effect on TMY (Table 1) in primiparous Kankrej cow and it is in close agreement with Dongre et al. (2017) and Parmar et al. (2019) for Deoni cattle and crossbred cattle, respectively. These findings are not in agreement of Narwaria et al. (2017) for Sahiwal cattle. In Table 1 result revealed that TMY of Kankrej cattle during different period was not differed significantly with each other. The least square analysis has revealed non-significant effect of sire on TMY in primiparous Kankrej cattle in comparison to 305 Days Milk Yield due to differences in the days which affecting the milk yield (Table 1).

\section{Lactation Length (LL)}

The least square means of lactation length (LL) of primiparous Kankrej cow based on 293 number of observation was $290.78 \pm$ 7.33 days (Table 1). These findings are in close association with the reports of Al-samarai et al. (2015) as 298.28 days for Holstein 
cow, Chaudhary (2016 lo-cit) as $300.90 \pm 10.31$ days for Kankrej cow, Mishra et al. (2016) as $294.93 \pm 2.58$ days for Tharparkar cattle and Kumar et al. (2017) as $288.55 \pm 19.41$ days for Sahiwal cattle. The results are contrast with the reports of Sawant et al. (2016); Chakravarthi et al. (2017) and Parmar et al. (2019).

The average LL of primiparous Kankrej cow, calvings during summer, monsoon and winter season was $291.63 \pm 9.09,292.55 \pm$ 11.08 and $288.14 \pm 8.70$ days, respectively. It was highest during monsoon season ( $292.55 \pm 11.08$ days), and minimum during winter season (288.14 \pm 8.70 days). However, effects of season of calving on LL of primiparous cow were non significant (Table: 1). The present findings are in close agreement with Ekka (2014) for Kankrej cattle, Bhutkar et al. (2014) for Deoni cattle and Dongre et al. (2017) for Deoni cattle. The present findings are contrast with the findings of Dangi et al. (2013) and Mishra et al. (2016). In table 1. result showed that LL of Kankrej cattle was not differed significantly with each other. Similarly, LL of the primiparous Kankrej cow were $280.61 \pm 26.94$ days, $313.55 \pm 15.99$ days, $282.97 \pm 14.07$ days and $285.97 \pm 14.01$ days during different periods of calving viz; P1, P2, P3 and P4, respectively. The highest LL was observed during $\mathrm{P} 2$ period (313.55 \pm 15.99 days) and lowest during P1 period ( $280.61 \pm 26.94$ days $)$ in primiparous cow but these values were non-significant (Table 1). These findings are supported by the Bhutkar et al. (2014); Kumar et al. (2014); Dongre et al. (2017) and Parmar et al. (2018). They reported that period of calving did not have any effect on LL. In table 1. result showed that LL of Kankrej cows was not differ significantly with each other. The effects of sire on LL of Kankrej cow (Table: 1) was observed non-significant. These finding are supported by the observations of Al-samarai et al. (2015) as they reported that sire effect on LL was non-significant.

\section{Conclusion}

The effects of non-genetic factors (season of calving, period of calving) on performance of primiparous Kankrej herd shows nonsignificant, whereas genetic factor (sire) has significant effect on 305 DMY under semi arid region of north Gujarat. On the basis of these observations, we can suggest that proper management practices as well as use of pedigreed/progeny tested sire will help to improve the production performance of the herd.

\section{References}

Ageeb AG, Hayes JF (2000) Genetic and environmental effects on the productivity of Holstein-Friesian cattle under the climatic conditions of Central Sudan. Tropical Anim Health Prod 32(1):33-49

Al-Samarai FR, Abdulrahman YK, Mohammed FA, Al-Zaidi FH, Al-Anbari NN (2015) Comparison of several methods of sires evaluation for total milk yield in a herd of Holstein cows in Yemen. Open Vet J 5: $11-17$

Anonymous, (2019) National Dairy Development- Annual Report-20182019. Available at https://nddb.coop/sites/default/files/ NDDB_AR_2018_19_Eng.pdf Accesed on 8th January, 2021
Ayeneshet B, Abera M, Wondifraw Z (2018) Reproductive and productive performance of Indigenous dairy cows under smallholder farmers management system in North. J of Fisheries Livest Prod 6: 1-5

Bala D, Momoh OM, Gwaza SD (2017) Effects of non-genetic factors affecting the productive performance of white Fulani and Friesian $\mathrm{x}$ White Fulani genotypes in Kaduna, Nigeria. J Appl Life Sci Int 15: $1-7$

Bhutkar SS, Thombre BM, Bainwad DV (2014) Effect of non genetic Factors on production traits in Deoni cows. J Agri Vet Sci 7: 09-14

Chakravarthi MK. Ekambaram B, Naik BR (2017) Growth and production performance of Sahiwal cattle in Andhra Pradesh. Int J Sci 6: 11401142

Chaudhary AP (2016 lo-cit) Kankrej breed: an increable germplasm of Zebu cattle. Indian J Anim Prod Manag 32: 150-160

Dangi PS, Singh R, Pundir RK, Singh A, Chaudhary V, Verma NK (2013) Study of various performance traits in Rathi cattle. Indian J Anim Res 47: 321-326

Dass G, Sadana DK (2000) Factors affecting some economic traits in Murrah buffaloes. Indian J Animal Res 37: 19-23

Dongre VB, Kokate LS, Jadhav PV, Salunke VM, Khandait VN, Durge SM, Patil PV (2017) Effect of non-genetic factors on production and reproduction traits in Deoni cattle. Int J Livest Res 7: 220-225

Ekka P, Gupta JP, Pandey DP, Shah RR (2014) Effect of non genetic factors on first lactation and reproduction traits in Kankrej cattle at North Gujarat. Indian Vet J 91: 18-20

Gaikwad US, Kamble SM, Deokar DK (2018) Studies on 305 days milk yield in Phule Triveni synthetic cattle. In Compedium of "Smallholders Livestock Producers in India Opportunities and Challenges" SDAU, Sardarkrushinagar, 11-13 April, 2018, Gujarat. pp. 21

Kakati P, Panchal D, Patel A, Bahuguna P, Joshi R, Rank D (2017) Genetic parameters of production and reproduction traits and factors affecting it in Frieswal cattle. Int J Livest Res 7: 190-199

Kishore K, Joshi RK, Kumar P, Pal RS (2016) Genetic and non-genetic factors affecting some reproduction traits in Tharparkar cattle. Vet Practitioner 17: 270-272

Kumar A, Mandal A, Gupta AK, Ratwan P, Kumar N (2017) Genetic evaluation of reproductive traits in Jersey crossbred heifers at an organized farm of eastern India. Indian J Anim Res 51: 619-624

Kumar N, Eshetie A, Abreha T, Yizengaw HA (2014) Productive performance of Indigenous and HF crossbred dairy cows in Gondar, Ethiopia. Vet World 7: 177-181

Kumar S, Dalal DS, Pander BL, Patil CS (2016a) Genetic evaluation of Crossbred cattle for Production traits. Haryana Vet 55: 137-140

Mandal A, Sachdeva GK (2001) Factors affecting production and reproduction performance of Crossbred cattle. Indian Vet J 78:745747

Mishra G, Siddiqui MF, Ingle VS, Meel MS (2016) Studies on production performance of Tharparkar cattle at organized farm. Int J Livest Res 7: 54-62

Narwaria US, Lathwal SS, Verma KK (2017) Non-genetic factors affecting milk production traits of Sahiwal cattle at organized dairy herd. Indian J Anim Prod Manag 33: 86-90

Parmar M, Shah SV, Darji VB (2019) Effect of month of calving on lactation yield of Crossbrd cattle. In Compedium of National Conference on Innovations in Animal Production for Sustainability and Doubling Farmers Income \& XXVI Annual Convention of the Indian Society of Animal Production and Management. Kerala Veterinary and Animal Science University, Kerala, 23-25 January, 2019, Kerala. pp. 73

Parmar M, Shah SV, Darji VB, Parmar DJ (2018) Effect of month of birth on lactation length of Crossbrd cows. In Compedium of "Smallholders 
Livestock Producers in India Opportunities and Challenges" SDAU, Sardarkrushinagar, 11-13 April, 2018, Gujarat. pp. 15

Rathod BS, Patel MP, Chaudhari AB, Gami YM and Panchasara HH (2020) Conservation and Improvement of Kankrej cattle (Bos indicus): status vis-s-vis strategies. Indian J Anim Sci 90:1130-1133

Rehman ZU, Khan SM, Bhatti, SA, Iqbal J, Iqbal A (2008) Factors affecting first lactation performance of Sahiwal cattle in Pakistan. Arch Tierz Dummerstorf 51: 305-317

Sawant P, Singh B, Sawant D, Yadav SP, Bhinchhar BK (2016) Effect of genetic and non genetic factors on first lactation traits in Gir cows. Indian J Anim Res 50: 872-876

Shingare VM, Chauhan DS, Bhise BR, Ghosh N (2015) Estimates of genetic parameters and trends of lactation performance traits of deoni cattle. Int J Repro Anim 5: 69-79

Singh A, Singh A, Singh M, Gupta AK, Dash SK (2016) Estimation of genetic parameters of first lactation 305-day and monthly test-day milk yields in Karan Fries cattle. Indian J Anim Sci 86: 436-440
Singh J, Singh CV (2016) Genetic and phenotypic parameters of first lactation and life time traits in Sahiwal cows. J Vet Sci Tech 7: 345

Singh J, Singh VK, Yadav AK, Jha AK (2017) Effect of genetic and nongenetic factors on age at first calving in Sahiwal cattle. Indian $\mathrm{J}$ Anim Res 51: 635-639

Singh U, Raja TV, Alyethodi, RR, Rathod BS, Prakash B, Bhasin V (2018) Genetic improvement of Kankrej cattle through associated herd progeny testing under field and farm conditions. Indian J of Animal Sci 88: 314-318

Singh VK, Neeraj, Pandey R, Mukherjee A (2020) Genetic study on performance traits in organized Holstein Friesian herd in India. Int J Sci Eng Appl Sci 6: 136-146

Vinoo R, Rao NG, Gupta RB, Rao BK (2005) Genetic study on productive and reproductive traits of Ongole cattle. Indian J Anim Sci 75: 438441 